\title{
Rise of major subaerial landmasses about 3.0 to 2.7 billion years ago
}

\section{C.-T. Liu ${ }^{1}$, Y.-S. He ${ }^{1 *}$}

Abstract

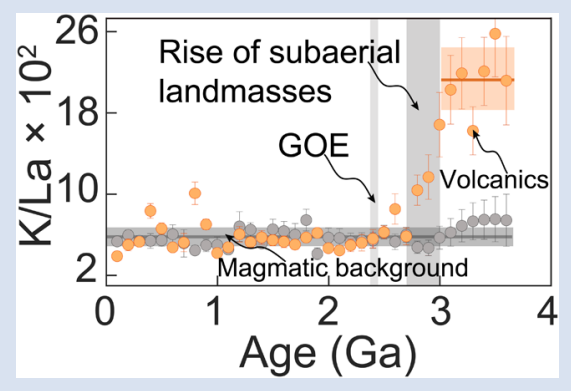

The emergence of subaerial landmasses should have inevitably modulated the chemical composition of the atmosphere-ocean and long term climate. However, it remains controversial when major subaerial landmasses first emerged in Earth's history. Here we show that the mean K/La of globally continental mafic volcanic rocks declined from a fairly high value ( 2125) to a magmatic background ( 582 , indicated by continental mafic plutonic rocks) during 3.0-2.7 Ga. It can only be explained by a progressive reduction in the proportion of submarine hydrothermally altered mafic volcanic samples and thus records a gradual rise of major subaerial landmasses from 3.0 to $2.7 \mathrm{Ga}$, likely to a present day level since $2.7 \mathrm{Ga}$. The rise and maintaining of major subaerial landmasses were intrinsically controlled by a dynamic balance of mountain building processes dominantly driven by plate tectonics and subsidence due to weathering erosion and thermal relaxation.

Received 4 December 2020 | Accepted 24 March 2021 | Published 25 May 2021

\section{Introduction}

Determining when major subaerial landmasses first emerged and how they rose is the key to understand secular evolution of Earth's ecosystem, but remains challenging. Static models considering multiple parameters (e.g., crustal thickness, density and mantle potential temperature) suggest the rise of major subaerial landmasses from the late Archean to the Neoproterozoic (Flament et al., 2008; Lee et al., 2017). Exposed landmasses have been traced back to as early as $\sim 3.5 \mathrm{Ga}$ (e.g., detrital sediments in the East Pilbara Craton; Buick et al., 1995; Campbell and Davies, 2017), as indicated by geological records of uplift-subsidence cycles (e.g., in the East Pilbara Craton during 3.5-3.2 Ga; Campbell and Davies, 2017). Early subaerial landmasses may have experienced subsidence and eventually submerged below sea level again, due to crustal erosion and thermal relaxation of continental lithospheric mantle root (Lee et al., 2017). Accordingly, it remains unclear to what extent sporadic geological records can reflect the relative proportion of subaerial landmasses with time.

An increase in subaerial large igneous provinces (LIPs) and a stepwise change of trip-oxygen-isotope $\left(\Delta^{17} \mathrm{O}\right)$ composition of shales indicate major landmasses could have rapidly emerged above sea level at the Archean-Proterozoic boundary (Kump and Barley, 2007; Bindeman et al., 2018). Most intriguingly, it was coincident with Earth's first blast of molecular oxygen (i.e. the Great Oxidation Event (GOE)) and has been proposed as a key driving force for the GOE, probably by increasing oxidised subaerial volcanic gases (Kump and Barley, 2007; Gaillard et al., 2011) and decreasing $\mathrm{O}_{2}$ sinks (e.g., $\mathrm{H}_{2}, \mathrm{CH}_{4}$ ) of weathering and alteration (Smit and Mezger, 2017). Both the number of subaerial LIPs and the $\Delta^{17} \mathrm{O}$ values of shales, however, appear too muted to reveal the emergence of subaerial landmasses. Here we show the mean K/La of global continental mafic volcanic rocks as a novel proxy to unravel the emergence history of subaerial landmasses.

\section{Rationale \& Results}

As highly incompatible elements, $\mathrm{K}$ and La do not fractionate from each other significantly during mafic magma processes. In contrast, $\mathrm{K}$ and La behaviour are very different during weathering and alteration at the surface. $\mathrm{K}$ is water-soluble and can thereby be easily removed during chemical weathering, while $\mathrm{La}$ is largely insoluble and thus immobile in this process. Weathered subaerial mafic rocks thus on average have depleted $\mathrm{K} / \mathrm{La}$ (Ma et al., 2007). With input from riverine runoff and high temperature $\left(>100\right.$ or $\left.150{ }^{\circ} \mathrm{C}\right)$ submarine hydrothermal processes (Hofmann and Harris, 2008; Staudigel, 2014), K is highly enriched relative to La in seawater. For submarine magma eruptions, the K/La of altered mafic volcanic rocks can be strongly elevated during low temperature hydrothermal alteration $\left(<100\right.$ or $\left.150{ }^{\circ} \mathrm{C}\right)$ with seawater (e.g., hydrothermally altered basalts; Fig. 1) (Hofmann and Harris, 2008; Staudigel, 2014; Supplementary Information). Therefore, mafic volcanic rocks in submarine eruptions are expected to possess systematically higher K/La compared to subaerial eruptions. Accordingly, the mean K/La of global continental mafic volcanic rocks could be an ideal proxy to track the relative proportion of submarine to subaerial eruptions over time.

\footnotetext{
State Key Laboratory of Geological Processes and Mineral Resources, China University of Geosciences (Beijing), Beijing 100083, China

Corresponding author (email: heys@cugb.edu.cn)
} 


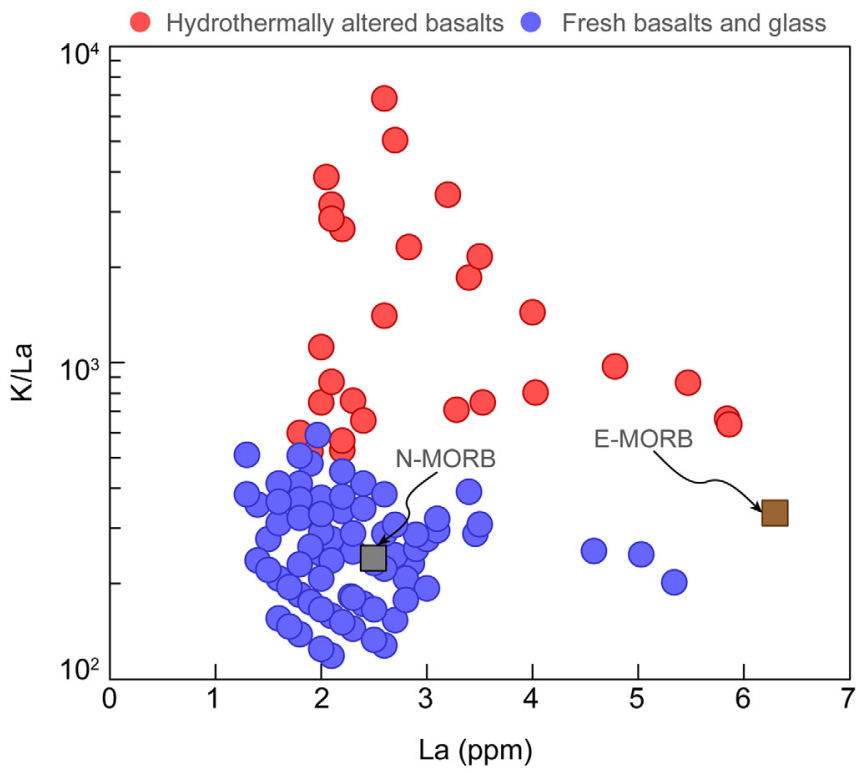

Figure $1 \mathrm{~K} / \mathrm{La}$ of fresh and hydrothermally altered basalts, exemplified by DSDP and ODP sites 417A, 417D, 418A, 801C, 843B, $1140 \mathrm{D}$ and $1149 \mathrm{~B}$ (see Supplementary Information). Mean normal mid-ocean ridge basalts (N-MORB) and enriched mid-ocean ridge basalts (E-MORB) are from Sun and McDonough (1989).

The weighted bootstrap re-sampling method with Monte Carlo simulations was applied to reveal secular changes in the $\mathrm{K} / \mathrm{La}$ of less differentiated $\left(\mathrm{SiO}_{2}: 43-51\right.$ wt. \%) global continental mafic volcanic and plutonic rocks (Fig. S-1) (Keller and Schoene, 2012; Supplementary Information). Mean K/La values of continental igneous rocks were calculated in $100 \mathrm{Ma}$ bins with uncertainty of 1 standard error of the mean (1 s.e.m.) (Fig. 2a, Table S-1). Mafic plutons intruded at depths and thus have been least affected by superficial seawater-rock interactions (Fig. S-2). Accordingly, these rocks can serve as a magmatic background, which yields a nearly constant mean $\mathrm{K} / \mathrm{La}$ since 3.6 Ga (582 \pm 92 , 1 standard deviation; 1 s.d.), whereas the mean $\mathrm{K} / \mathrm{La}$ of mafic volcanic rocks exhibits a substantial change through time. What is striking in mafic volcanic rocks is much higher mean $\mathrm{K} / \mathrm{La}$ at pre-3.0 Ga-yielding an average value of $2125 \pm 309$ (1 s.d.) - that progressively decline to near the magmatic background ( $584 \pm 83,1$ s.e.m.) at $2.7 \mathrm{Ga}$. Three transient positive excursions of $\mathrm{K} / \mathrm{La}$ have been identified for post-2.7 Ga mafic volcanic rocks, i.e. at $0.4,0.8$ and $2.6 \mathrm{Ga}$, coincident with global tectono-magmatism lulls (Voice et al., 2011; Hawkesworth et al., 2017). Without considering these excursions, the mean $\mathrm{K} / \mathrm{La}$ of post-2.7 Ga mafic volcanic rocks yield an average of $536 \pm 74$ (1 s.d.) statistically lower than the magmatic background ( $t$ test, $p<0.01$ ). It indicates distinguishable $\mathrm{K}$ depletion relative to $\mathrm{La}$ in post-2.7 Ga volcanic rocks relative to their intrusive equilibrants (Fig. 2a).

\section{Discussion}

With the development of plate tectonics (Tang et al., 2016), differentiation in subduction zones and recycling of crustal materials created substantial mantle heterogeneity. On the one hand, influx of more K relative to La into the mantle wedge via aqueous fluids derived from subducted sediments and oceanic slabs (Kelemen et al., 2014), tends to produce arc basalts with elevated K/La (e.g., average of continental arc basalts; Fig. 2a). On the other hand, recycling of dehydrated crustal materials can account for some intra-plate basalts with depleted K/La

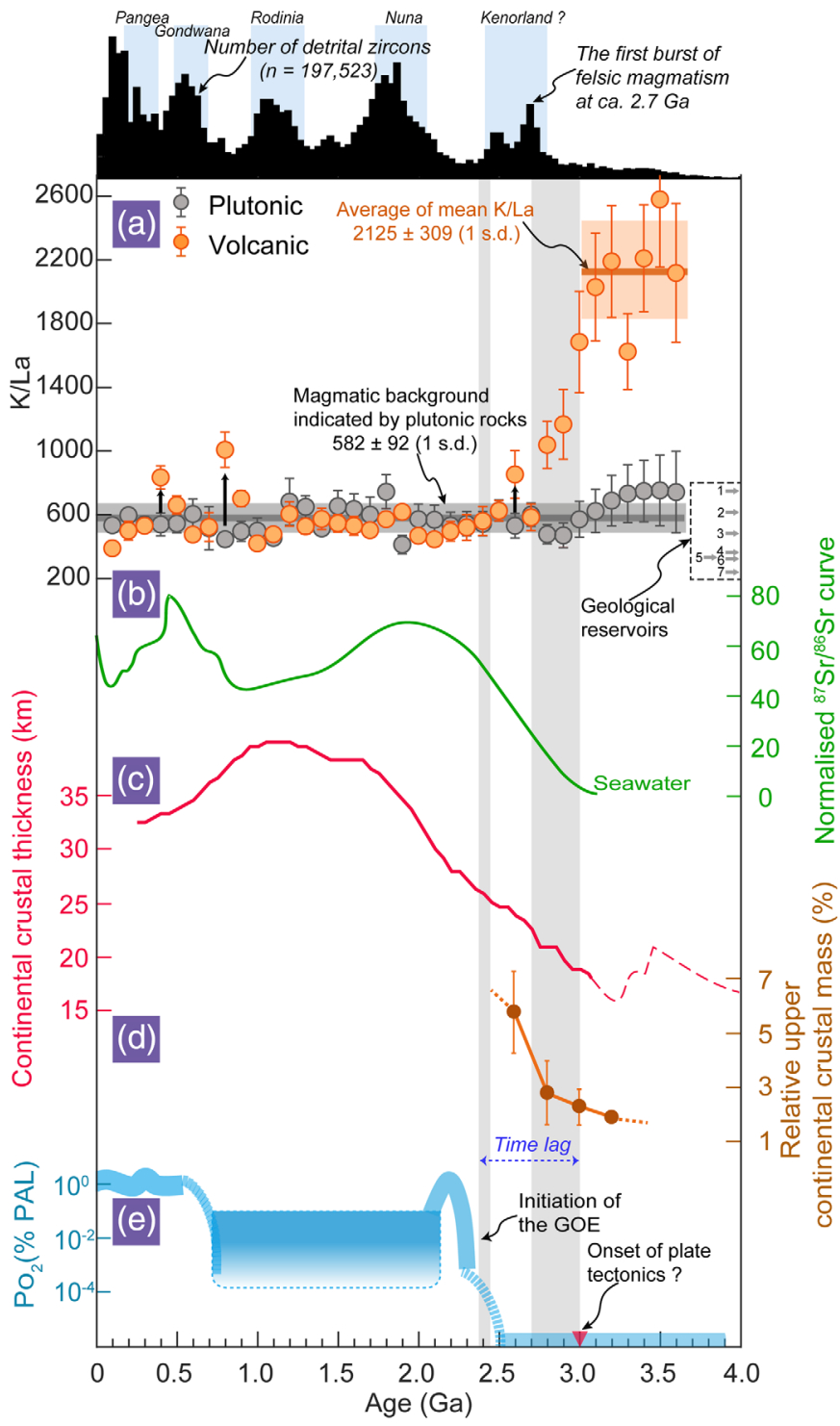

Figure 2 (a) Secular mean K/La evolution of global continental mafic volcanic and plutonic rocks. Error bars show 1 s.e.m. uncertainties. Modern geological reservoirs are shown as grey arrows with numbers: (1) upper continental crust, (2) continental arc basalts, (3) lower continental crust, (4) primitive mantle, (5) E-MORB, (6) ocean island basalts (OIB), (7) N-MORB (Sun and McDonough, 1989; Kelemen et al., 2014; Rudnick and Gao, 2014). Secular changes in (b) normalised seawater ${ }^{87} \mathrm{Sr} /{ }^{86} \mathrm{Sr}$ curve (Shields et al., 2007), (c) the juvenile continental crustal thickness (Dhuime et al., 2015), (d) the upper continental crustal mass (Tang et al., 2016), and (e) atmospheric $\mathrm{O}_{2}$ level (Lyons et al., 2014) are also shown for comparison. Global detrital zircon U-Pb age distribution (Voice et al., 2011) is plotted at the top of the figure, with the periods of supercontinents assembly (Hawkesworth et al., 2017).

(e.g., average K/La values of Deccan Traps and Siberia LIPs are 201 and 161, respectively; Farmer, 2014). However, development of mantle reservoirs with differentiated K/La (e.g., OIB, N-MORB, E-MORB; Sun and McDonough, 1989) appears not to have significantly changed the mean K/La of global mafic magmas with time, as illustrated by nearly constant mean $\mathrm{K} / \mathrm{La}$ of mafic plutons since 3.6 Ga (Fig. 2a).

Crustal contamination can elevate $\mathrm{K} / \mathrm{La}$ of continental mafic magmas to various extents by interaction with felsic continental crust with a higher $\mathrm{K} / \mathrm{La}$ (Fig. 2a). On the contrary, $\mathrm{K}_{2} \mathrm{O} / \mathrm{Na}_{2} \mathrm{O}$ of felsic continents increases since $\sim 3.0$ Ga reaching a modern 
value at $\sim 2.5 \mathrm{Ga}$ (Fig. S-3). Contamination by felsic continental crust thus cannot explain the nearly contemporaneous decline in the mean K/La of mafic volcanic rocks. Further, mean K/La values of global mafic volcanic rocks at pre-2.7 Ga are too high ( 1039-2580; Table S-1) to be explained by crustal contamination, as the mean $\mathrm{K} / \mathrm{La}$ of the modern upper continental crust is only 750 (Rudnick and Gao, 2014; Fig. 2a). Archean mafic volcanic and plutonic samples could both have been subjected to metamorphism. However, the nearly invariable mean K/La of mafic plutonic rocks over time indicates that metamorphism may have not significantly changed mean $\mathrm{K} / \mathrm{La}$ of global mafic rocks.

The mean $\mathrm{K} / \mathrm{La}$ of mafic volcanic rocks prior to $\sim 3.0 \mathrm{Ga}$ is too high to be subjected to any magmatic and metamorphic origin. Instead, such high values, to our knowledge, can only be explained by influence of widespread low temperature seawater-rock interactions on these mafic volcanic rocks (Figs. 1, S-2). Therefore, the remarkably elevated mean K/La of pre-3.0 Ga mafic volcanic rocks reveals magma eruptions predominantly at a submarine environment (Fig. 3a), supporting the consensus that most early Archean landmasses were still below sea level (Bindeman et al., 2018). The mantle-like seawater ${ }^{87} \mathrm{Sr} /{ }^{86} \mathrm{Sr}$ compositions in pre-3.0 Ga (Shields, 2007; Fig. 2b) may also reflect limited erosion of proto-landmasses and a largely submarine state for early Archean landmasses.
Potassium mobility could be quite different during anoxic versus oxic alteration of basalts (Jagoutz, 2012). Saponite forms in anoxic altered basalts while celadonite forms in oxic altered basalts. The former mineral contains a much lower $\mathrm{K}_{2} \mathrm{O}$ content than the latter one. Therefore, transition from widespread anoxic to oxic alteration across the GOE would predict a systematic increase in the $\mathrm{K} / \mathrm{La}$ of global mafic volcanic rocks, which is inconsistent with the reverse trend observed in Figure 2a. Instead, the progressive decrease in mean $\mathrm{K} / \mathrm{La}$ of mafic volcanic rocks during $\sim 3.0-2.7 \mathrm{Ga}$ may reflect a gradual decline in the proportion of magmas that erupted at submarine environments and experienced hydrothermal alteration, in other words, the emergence of subaerial landmasses (Fig. 3b). After this transition, the relatively steady mean $\mathrm{K} / \mathrm{La}$ of mafic volcanic rocks suggests that, on the whole, the area of subaerial landmasses has not significantly changed since $\sim 2.7 \mathrm{Ga}$. Statistical analysis on the mean $\mathrm{K} / \mathrm{La}$ of global mafic volcanic and plutonic rocks thus provides a compelling record for the rise of major subaerial landmasses during $\sim 3.0-2.7 \mathrm{Ga}$, likely to a present day level since $\sim 2.7$ Ga (Figs. 2a, 3b).

The gradual rise of major subaerial landmasses during 3.0-2.7 Ga can be supported by multiple geological observations. Emergence of large subaerial landmasses initially occurred at $\sim 3.0 \mathrm{Ga}$ at the Kaapvaal craton (e.g., Pongola-Wiwatersrand
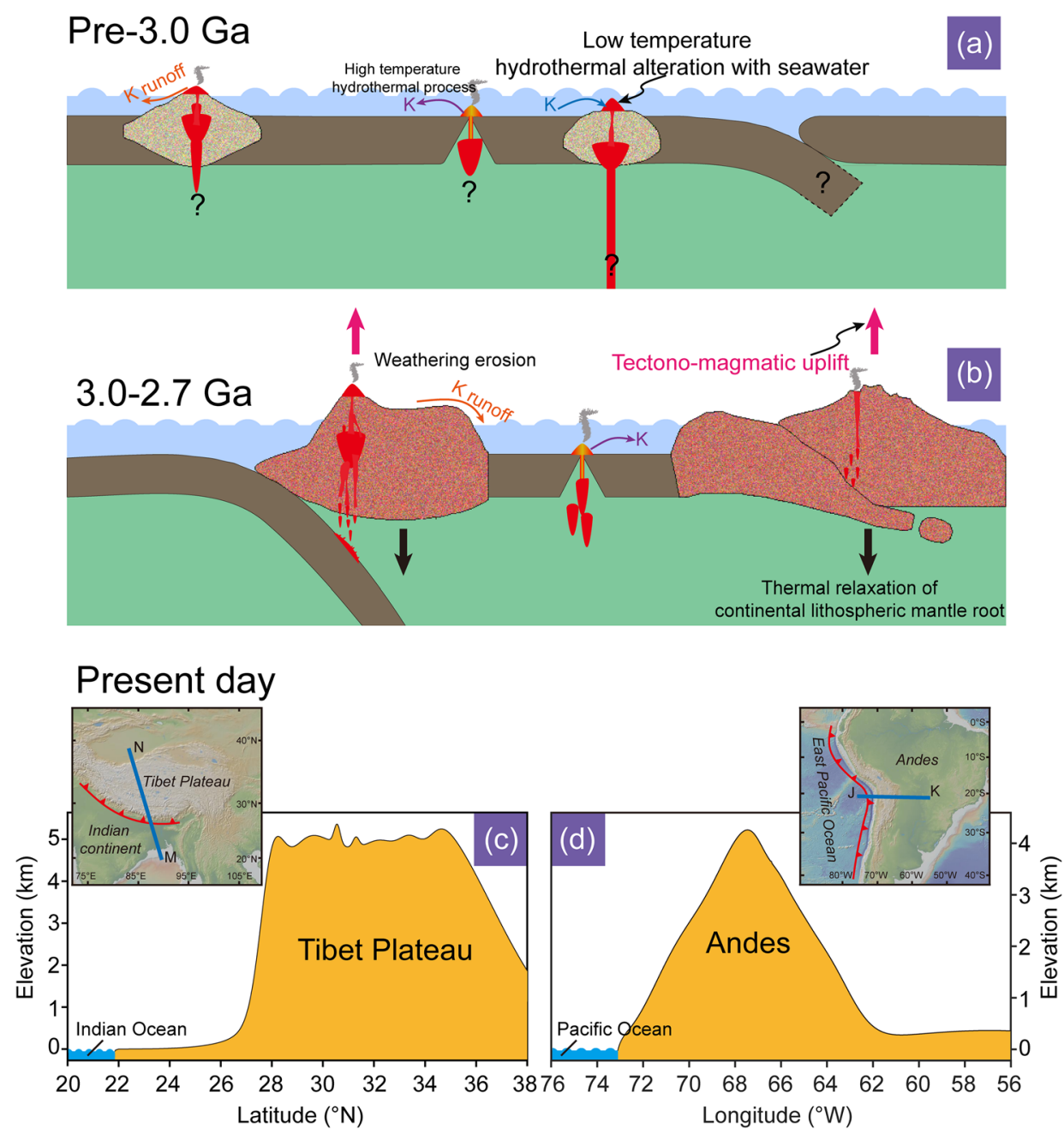

Figure 3 Schematic diagrams illustrating submarine versus subaerial states of landmasses in the Archean era. (a) Largely submarine state of proto-landmasses at pre-3.0 Ga. (b) Rise of subaerial landmasses during $\sim 3.0-2.7 \mathrm{Ga}$, likely driven by initiation of plate tectonics and assembly of the first supercontinent. These tectono-magmatic events can create high elevations as happens at present day (c) Tibet and (d) Andes plateaus (see Supplementary Information). 
Basin; with an area of hundreds of square kilometres of exposed surface; Kump and Barley, 2007; Korenaga et al., 2017) that then extended to various cratons at $\sim 2.7 \mathrm{Ga}$ (e.g., KalgoorlieKambalda, Abitibi, Slave, Dharwar, Zimbabwe, Wyoming, Kaapvaal and Pilbara; Kump and Barley, 2007; Campbell and Davies, 2017). Increasing seawater ${ }^{87} \mathrm{Sr} /{ }^{86} \mathrm{Sr}$ isotopic ratios since $\sim 3.0$ Ga may reflect more extensive chemical weathering of exposed landmasses at that time (Fig. 2b). The earliest mature detrital zircon age distributions at $\sim 3.0-2.8 \mathrm{Ga}$ also indicates widespread rise of subaerial continents at that time (Reimink et al., 2021).

The area of global subaerial landmasses in Earth's history is regulated by water volume in the hydrosphere, topography differentiation driven by tectono-magmatic events (likely what happens at present day Tibet and Andes plateaus; Fig. 3c,d) as well as processes that eliminate topography difference, e.g., weathering erosion and subsidence due to thermal relaxation of continental lithospheric mantle root (Lee et al., 2017). More than $50 \%$ water in the hydrosphere has been suggested to be returned back to the mantle through subduction in the past (Korenaga et al., 2017). Here we consider that the decline in the total water volume of the hydrosphere was minor during the rise of major subaerial landmasses, as Archean subduction zones, if they existed, were hot and deep subduction of water should have been prevented by prevailing slab melting (Rapp et al., 2003).

Crustal thickness plays an important role in controlling continental elevations (Lee et al., 2017). Rapid growth of crustal thickness as well as felsic components since $\sim 3.0 \mathrm{Ga}$ (Tang et al., 2016; Dhuime et al., 2015) should have increased continental elevations. However, static models with consideration of the crustal thickness, density and mantle potential temperature predict the rise of major subaerial landmasses until the Neoproterozoic (Lee et al., 2017). Instead, the rise of major subaerial landmasses during 3.0-2.7 Ga can be explained by initiation of plate tectonics ( 3.0 Ga; Tang et al., 2016) and assembly of the Earth's first supercontinent (Kenorland), which was marked by the first burst of felsic magmatism at 2.7-2.5 Ga (Voice et al., 2011; Hawkesworth et al., 2017; Fig. 2). Continuous subduction with the episodic assembly of supercontinents could have provided persistent mountain building processes globally, which must have largely overcome weathering erosion and thermal subsidence to keep the area of global subaerial landmasses nearly constant since $\sim 2.7 \mathrm{Ga}$. The three K/La positive excursions of mafic volcanic rocks may have recorded several periods with a shrunken area of global subaerial landmasses, which can be explained by weaker orogeny during tectono-magmatic lulls (Fig. 2a).

Submarine landmasses universal in the early Archean, indicated by the extremely high mean $\mathrm{K} / \mathrm{La}$ of mafic volcanic rocks (Figs. 2a, 3a), with widespread submarine hydrothermal processes and serpentinisation of ultramafic-mafic rocks could have buffered a reduced atmosphere (Smit et al., 2017) and provided proper environments (e.g., $\mathrm{N}_{2}, \mathrm{H}^{+}$, temperature) for early life (Sleep et al., 2011). For instance, $\mathrm{H}_{2}$-rich fluids were likely to support the prosperity of methanogens and promote complex organic compounds (biotic or prebiotic life) in pristine seas (Hofmann and Harris, 2008). Intriguingly, the emergence of subaerial landmasses has been proposed as a key driving force for the GOE (Kump and Barley, 2007; Gaillard et al., 2011). A "time lag" is identified here between the rise of major subaerial landmasses and the initiation of the GOE (Lyons et al., 2014; Fig. 2e). This time lag may not be explained by the delayed response of the surficial systems to evolution of the solid Earth, if a steady atmospheric oxygen level could be established at a time scale $<50 \mathrm{Ma}$ (Laakso and Schrag, 2014). Accordingly, the emergence of subaerial landmasses during 3.0-2.7 Ga most likely acted as a precondition rather than a trigger for the GOE. This study suggests alternative mechanisms, e.g., the evolution of oxygen photosynthesis, sedimentary burial of organic carbon (Lyons et al., 2014) and/or deep oxygen cycles driven by volatiles (He et al., 2019), have eventually triggered the GOE.

\section{Author Contributions}

Y-SH designed the project. C-TL compiled the datasets and conducted the MATLAB coding. Both authors interpreted the results and prepared the manuscript.

\section{Acknowledgements}

The authors appreciate C.B. Keller for his generous and helpful suggestions about theory of the weighted bootstrap resampling method. K. Qu and Y.-Z. Ge provided help with coding. This work was supported by the National Science Foundation of China (Nos. 41688103 and 41730214), the Fundamental Research Funds for the Central Universities (3-7-5-2019-07), the 111 Project of the Ministry of Science and Technology, China (Grant No. BP0719021) and State Key Lab of Geological Processes and Mineral Resources. This is CUGB petrogeochemical contribution No. PGC-201565.

Editor: Cin-Ty Lee

\section{Additional Information}

Supplementary Information accompanies this letter at https:// www.geochemicalperspectivesletters.org/article2115.

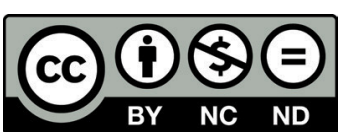

(C) 2021 The Authors. This work is distributed under the Creative Commons Attribution NonCommercial No-Derivatives 4.0 License, which permits unrestricted distribution provided the original author and source are credited. The material may not be adapted (remixed, transformed or built upon) or used for commercial purposes without written permission from the author. Additional information is available at https://www. geochemicalperspectivesletters.org/copyright-and-permissions.

Cite this letter as: Liu, C.-T., He, Y.-S. (2021) Rise of major subaerial landmasses about 3.0 to 2.7 billion years ago. Geochem. Persp. Let. 18, 1-5.

\section{References}

Bindeman, IN, ZaKharov, D.O, Palandri, J Greber, N.D, Dauphas, N. Retallack, G.J., Hofmann, A., Lackey, J.S., BeKKer, A. (2018) Rapid emergence of subaerial landmasses and onset of a modern hydrologic cycle 2.5 billion years ago. Nature 557, 545-548.

Butck, R., Thornett, J.R., McNaughton, N.J., Smith, J.B., Barley, M.E., Savage, M. (1995) Record of emergent continental crust $\sim 3.5$ billion years ago in the Pilbara craton of Australia. Nature 375, 574-577.

Campbell, I.H., Davies, D.R. (2017) Raising the continental crust. Earth and Planetary Science Letters 460, 112-122.

Dhuime, B., Wuestefeld, A., HawKesworth, C.J. (2015) Emergence of modern continental crust about 3 billion years ago. Nature Geoscience 8, 552-555.

FARMER, G.L. (2014) 4.3 - Continental Basaltic Rocks. In: Holland, H.D., TureKIAN, K.K. (Eds.) Treatise on Geochemistry. Second Edition, Elsevier, Oxford, 75-110

Flament, N., Coltice, N., Rey, P.F. (2008) A case for late-Archaean continental emergence from thermal evolution models and hypsometry. Earth and Planetary Science Letters 275, 326-336. 
Gaillard, F., Scaillet, B., ARndt, N.T. (2011) Atmospheric oxygenation caused by a change in volcanic degassing pressure. Nature 478, 229-232.

Hawkesworth, C.J., CAwood, P.A., Dhuime, B., Kemp, T.I.S. (2017) Earth's continental lithosphere through time. Annual Review of Earth and Planetary Sciences 45, 169-198.

He, Y.-S., Meng, X.-N., Ke, S., Wu, H.-J., Zhu, C.-W., Teng, F.-Z., Hoefs, J HuANG, J., YANG, W. XU, L.-J., Hou, Z.-Q., ReN, Z.-Y., LI, S.-G. (2019) A nephelinitic component with unusual $\delta^{56} \mathrm{Fe}$ in Cenozoic basalts from eastern China and its implications for deep oxygen cycle. Earth and Planetary Science Letters 512, 175-183.

Hofmann, A., HarRIs, C. (2008) Silica alteration zones in the Barberton greenstone belt: A window into subseafloor processes 3.5-3.3 Ga ago. Chemical Geology 257, 221-239.

JAGOUTZ, O. (2012) Were ancient granitoid compositions influenced by contemporaneous atmospheric and hydrosphere oxidation states? Terra Nova 25, 95-101.

Kelemen, P.B., Hanghøj, K., Greene, A.R. (2014) 4.21 - One View of the Geochemistry of Subduction-Related Magmatic Arcs, with an Emphasi on Primitive Andesite and Lower Crust. In: Holland, H.D., Turekian, K.K. (Eds.) Treatise on Geochemistry. Second Edition, Elsevier, Oxford, 749-806.

Keller, C.B., Schoene, B. (2012) Statistical geochemistry reveals disruption in secular lithospheric evolution about 2.5 Ga ago. Nature 485, 490-493.

Korenaga, J., Planavsky, N.J., Evans, D.A.D. (2017) Global water cycle and the coevolution of the Earth's interior and surface environment. Philosophical Transactions of the Royal Society A-Mathematical Physical and Engineering Sciences 375, 20150393

Kump, L.R., BarLeY, M.E. (2007) Increased subaerial volcanism and the rise of atmospheric oxygen 2.5 billion years ago. Nature 448, 1033-1036.

LAaKSO, T.A., SchraG, D.P. (2014) Regulation of atmospheric oxygen during the Proterozoic. Earth and Planetary Science Letters 388, 81-91.

Lee, C.-T.A., Caves, J., Jiang, H.-H., CaO, W.-R., Lenardic, A., McKenzie, N.R. Shorttle, O., YIN, Q.-Z., DYer, B. (2017) Deep mantle roots and continental emergence: implications for whole-earth elemental cycling, long-term climate, and the Cambrian explosion. International Geology Review 4, 431-448.

Lyons, T.W., Reinhard, C.T., Planavsky, N.J. (2014) The rise of oxygen in Earth's early ocean and atmosphere. Nature 506, 307-315

MA, J.-L., WeI, G.-J., XU, Y.-G., LonG, W.-G., Sun, W.-D. (2007) Mobilization and re-distribution of major and trace elements during extreme weathering of basalt in Hainan Island, South China. Geochimica et Cosmochimica Acta 71, 3223-3237.

RAPP, R.P., SHIMIZU, N., NORMAN, M.D. (2003) Growth of early continental crust by partial melting of eclogite. Nature 425, 605-609.

ReImINK, J.R., DAvies, J.H.F.L., IelPI, A. (2021) Global zircon analysis records gradual rise of continental crust throughout the Neoarchean. Earth and Planetary Science Letters 554, 116654

Rudnick, R.L., GaO, S. (2014) 4.1 - Composition of the Continental Crust. In: Holland, H.D., TureKIAN, K.K. (Eds.) Treatise on Geochemistry. Second Edition, Elsevier, Oxford, 1-51.

SHIELDS, G.A. (2007) A normalised seawater strontium isotope curve: possible implications for Neoproterozoic-Cambrian weathering rates and the further oxygenation of the Earth. eEarth 2, 35-42.

SleEP, N.H., BiRD, D.K., Pope, E.C. (2011) Serpentinite and the dawn of life Philosophical Transactions of the Royal Society B-Biological Sciences 366, 2857-2869.

Smit, M.A., Mezger, K. (2017) Earth's early $\mathrm{O}_{2}$ cycle suppressed by primitive continents. Nature Geoscience 10, 788-792.

Staudigel, H. (2014) 4.16 - Chemical Fluxes from Hydrothermal Alteration of the Oceanic Crust. In: Holland, H.D., TureKIAN, K.K. (Eds.) Treatise on Geochemistry. Second Edition, Elsevier, Oxford, 583-606.

Sun, S.-S., McDonough, W.F. (1989) Chemical and Isotopic Systematics of Oceanic Basalts: Implications for Mantle Composition and Processes. Geological Society, London, Special Publications 42, 313-345.

TANG, M., CHEN, K., RUDNICK, R.L. (2016) Archean upper crust transition from mafic to felsic marks the onset of plate tectonics. Science 351, 372-375.

VoICE, P.J., KOWALEWSKI, M., ERIKSSON, K.A. (2011) Quantifying the timing and rate of crustal evolution: global compilation of radiometrically dated detrital zircon grains. Journal of Geology 119, 109-126. 